\title{
Race and Caste: Its Impact on the American Political System
}

\author{
Howard A. Palley1,2 \\ ${ }^{1}$ School of Social Work, University of Maryland, Baltimore, USA \\ ${ }^{2}$ Institute for Human Services Policy, University of Maryland, Baltimore, USA \\ Email: HPALLEY@ssw.umaryland.edu
}

How to cite this paper: Palley, H. A. (2021). Race and Caste: Its Impact on the American Political System. Open Journal of Political Science, 11, 479-487.

https://doi.org/10.4236/ojps.2021.113032

Received: April 11, 2021

Accepted: July 16, 2021

Published: July 19, 2021

Copyright $\odot 2021$ by author(s) and Scientific Research Publishing Inc. This work is licensed under the Creative Commons Attribution International License (CC BY 4.0).

http://creativecommons.org/licenses/by/4.0/

\begin{abstract}
The American Constitution's commitment to "secure the blessings of liberty to ourselves and our posterity" did not include the enslaved black population that suffered the cruelty of chattel slavery. The black population was not considered full citizens. This essay contends that the residue of this situation still affects U.S. politics-in a significant manner. This analysis examines the historical background of race and caste in American society. It includes the political history of race and caste in the political process since the passage of the Civil Rights Act of 1964 and the Voting Rights Act of 1965 up until contemporary events-including contemporary politics.
\end{abstract}

\section{Keywords}

Race, Caste, "The American Dilemma”, Voting Rights

\section{The White Whale: Introduction and Context}

In 2007 in an address to the American Academy of Arts and Sciences and the American Philosophical Society entitled "The White Whale" later published in The Nation, E.L. Doctorow (2008) warned about the problem of racism as part of an unfortunate response to the inability to deal with the complexities of life in contemporary American society. He observed that American politics could be viewed "as a struggle between the idealistic secular democracy of a fearlessly self-renewing America and a kind of water wonderland whale made up of racism, nativism [and] cultural illiteracy..." (2008). This paper will trace the dilemma of securing basic human rights_-"the blessings of Liberty to ourselves and our Posterity" with our history of slavery, segregation, racial discrimination and the continuing struggle to secure voting rights for all citizens without estab- 
lishing barriers that would limit those rights.

Given the complexity of contemporary society Doctorow (2008) noted insightfully: "What is more natural than to rely on the saving powers of simplism?" The simplism of racial discrimination this paper maintains is a threat to our democracy and that the politics of race in the United States is a major element of this threat.

\section{The Caste System in the United States}

One of the dysfunctional elements of American society that concerns Doctorow is the American caste system based on a color code of "white" and "black" as essential caste features. The caste system in colonial America was, in part, a response to Bacon's Rebellion (led by Nathan Bacon) in 1676 where free blacks and whites-including white indentured servants combined in opposition to William Berkeley, the Governor of Virginia, in seeking to legitimize claims to land and resources in Virginia's frontier. This resulted in their burning Jamestown (Kunzru, 2020). In seeking to undermine such future alliances, a 1691 Virginia statute articulated a social and legal identity in which being white was "higher" than being black. This hardening of class lines eventually resulted in the Virginia Slave Codes of 1705 (Foner, 2009: p. 100). This white/black hierarchy of caste was summarized by W.E.B. DuBois in Black Reconstruction in America. DuBois (1935) observed that " $\ldots$ the white group of laborers, while they received a low wage, were compensated in part by a sort of public and psychological wage. They were given public deference and titles of courtesy because they were white. They were admitted freely with all classes of white people to public functions, public parks and the best schools. The police were drawn from their ranks and the courts, dependent on their votes, treated them with leniency as to encourage lawlessness."

Such "white supremacy" in its historic extreme forms resulted in anti-black riots and the lynching of blacks (Roediger, 1999). One manifestation of this was the New York riots of July 1863. Protesting against conscription between an estimated 1200 to 1500 mostly Irish dockworkers rioted for four days targeting blacks some of whom were also dockworkers. The severity of these riots was such that after the riots, the black population of New York diminished by 20 percent and black dockworkers were supplanted by Irish longshoremen (Man Jr., 1951).

Also immigrant groups low on the hierarchy of caste could be "admitted" to whiteness. Following the lynching of 11 Italian immigrants in New Orleans in 1892, President Benjamin Harrison declared Columbus Day a onetime national celebration in an effort to placate Italian Americans and ameliorate diplomatic strains with Italy (Belamonte Jr., 1999; Staples, 2020). Later, in 1934, Congress passed a statute that requested a Presidential Proclamation that October 12 be set aside as Columbus Day celebrating "the discovery" of America. President Franklin D. Roosevelt responded by making such a proclamation. 


\section{The Rise of the Segregated South}

To understand the role of racism specifically within the contemporary Republican Party, it is necessary to examine the post Civil War period and the rise of a racially segregated tenant farmer system in which blacks were assigned the lowest wrung and were effectively politically disfranchised. During Reconstruction, 1865 to 1877 , for a time biracial Republican dominated governments represented the former Confederate states. These governments funded public schools and promoted improvements in public transportation and shipping.

However southern white militias and terrorist organization such as the Ku Klux Klan gradually undermined these governments through a process of white terror and intimidation which returned power to a white "gentry" where the black population was largely limited, as has been noted, to a system of tenant farming . One example of the process of white terror that eliminated the application of the $13^{\text {th }}$, $14^{\text {th }}$ and $15^{\text {th }}$ Constitutional Amendment guarantees for black Americans is the violent white racist coup of government in Wilmington, North Carolina in November, 1898 (Blight, 2020; Zucchino, 2021). The last federal troops in the "Confederate" South had been withdrawn in 1877 from South Carolina, Louisiana and Florida. In the period from 1890 to 1910, the former Confederate states promulgated new constitutions or amendments that disenfranchised most blacks and many poor whites through a combination of poll taxes, literacy and comprehension tests and residency and record keeping requirements. This resulted in a white dominated segregated South under the political control of Southern whites associated with the Democratic Party. Further segregation affecting federal employment in agencies such as U.S. Post Office, the Bureau of Engraving and Printing, the Navy, the Interior Department and the War Department occurs under the Democratic Administration of Woodrow Wilson (Yellin, 2016). This system of Southern white Democratic Party dominance in the former Confederacy essentially is sustained until President Lyndon Johnson signs the Civil Rights Act of 1964 ending formal segregation and the Voting Rights Act of 1965 protecting the right to vote of black Americans in the former segregated South and also to such non-southern segregated, formerly slave states, as Maryland and Delaware. Mass murders of black communities also occurred outside the South, such as white marauding of the community of Greenwood in Tulsa, Oklahoma on June 1, 1921 (Staples, 2020).

\section{The Republican Use of a Southern Strategy}

Nevertheless the aforementioned events lead to subtle and not so subtle racial appeals by politicians associated with the Republican Party. This is the basis of what was termed the Republican Party's Southern Strategy. Initially, Barry Goldwater in his 1964 run for the Presidency incorporated "Operation Dixie" which emphasized his vote against the Civil Rights Act of 1964 (Maxwell, 2019). This did not prove to be successful although he did win the electoral votes of Mississippi as well as Arizona. A more sophisticated form of the Southern Strategy was 
used by Richard Nixon in his 1968 and 1972 Presidential campaigns. In addition to appealing to white racial grievance, he appealed to white evangelical grievances against secular initiatives and emphasized women's "homemaker" role in society (Maxwell, 2019). In his 1976 Presidential campaign, his "law and order" message signaled his opposition to protests and marches; his "war on drugs" contained an element of appealing to those fearful of black crime. He also was to adopt a policy of "benign neglect" with regard to civil rights enforcement.

At the presidential level a few events characterize this movement. In his unsuccessful 1976 campaign for the Republican presidential nomination. Ronald Reagan used racial allusions denigrating "welfare queens" and "strapping young bucks" who purchased t-bone steaks with Food Stamps. He initiated his 1980 campaign with a speech supporting "states' rights" delivered just outside Philadelphia, Mississippi-the site of the murder of three young civil rights workers, James Chaney, Michael Schwermer and Andrew Goodman, by local Klu Klux Klan members in 1964. His speech was delivered at the Neshoba County Fair - a location within walking distance from the earthen dam where the murdered civil rights workers had been buried 16 years earlier. In his 1984 re-election campaign he returned to Philadelphia, Mississippi and in his speech declared the "the South shall rise again" (Schwart, 2015). On the occasion of Reagan's death the columnist, William Raspberry, observed that Reagan's endorsement of "states' rights," a phrase white Southerners used to justify racial segregation, was a "bitter symbolism for black Americans [and] an important bouquet for [Republican] courtship of white 'Dixiecrats'." He concluded that Reagan “... racially... left us a more divided nation, in part by making division seem legitimate.” Reagan also opposed the Civil Rights Act of 1964 and the Voting Rights Act of 1965 although as President he signed the 25 year extension of the Voting Rights Act of 1982 (Ross, 2020).

Another deeply racial appeal was George H. W. Bush's campaign use of "the Willie Horton" political ad in the 1988 Presidential campaign presenting the face of a furloughed black prisoner, previously involved in a murder, who had committed a rape of a white woman and a stabbing of her boyfriend. The ad indicated that his opponent, George Dukakis, was personally insufficiently concerned with kidnapping, stabbing and rape and was too lenient with regard to murderers in spite of the fact that such furloughs were common in many states. Bush frequently returned to this "dog-whistle" racism subject throughout his campaign. Critics noted that Bush conducted "a brutal low campaign" playing on white fears of black crime. A more recent commentator noted that: "George H.W. Bush's 'Willie Horton' ...will always be the reference point for dog-whistle racism" (Withers, 2018). Indeed commenting on the Willie Horton ad, Presidential political advisor Lee Atwater had observed: "The Horton case is one of the gut issues, particularly in the South. And if we hammer at that these [sic] over and over we are going to win" (Schwartzapful \& Keller, 2015).

In an earlier 1981 interview Atwater had explained how one could win the 
votes of racists without being explicitly racist and how this was particularly effective in the South:

"You start out in 1954 by saying [multiple use of the 'n' word]. By 1968 you can't say 'n...' that hurts you, backfires. So you stay stuff like, uh, forced busing, states' rights, and all that stuff, and you're getting so abstract. Now your talking about cutting taxes, and all these things your talking about are totally economic things and a byproduct of them is, blacks get hurt worse than whites.... 'We want to cut this,' is much more abstract than even the busing thing, uh, and a hell of a lot more abstract than 'N...', 'n...'” (Perlstein, 2012).

Contemporary Use of Racial Appeals in Recent Presidential Politics

Donald Trump has contributed a much more overt and less subtle advance to this strategy of appealing to racism. Trump embraced "birtherism." Birtherism was a trope that originated on "black sites." Its thesis was that President Barak Obama was born outside the United States, was a non U.S. citizen and was not a legitimate President. Furthermore it indicated he was a Muslim and a terrorist wishing to harm the United States (Wehner, 2011). Trump articulated the first part of this trope-that Obama was not a legitimate President. In March, 2011 he asserted to Fox News that: "He doesn't have a birth certificate, He may have one, there is something on the birth certificate-maybe religion, maybe it says he's a Muslim." He went on to assert: "I have people that have been studying it and they cannot believe what they are finding" (Serwer, 2020). Subsequent polls indicated that half of Republican voters believed that Obama was born abroad. This led Obama to release his long form birth certificate indicating his birth in Hawaii. Nevertheless, this racist trope gave comfort to those who wished to declare that this biracial president was an illegitimate president. Examining Trump's overwhelmingly white audiences one may reach the conclusion that his slogan, "Make America Great Again", is an allusion to a time "when white political and cultural hegemony was unthreatened by black people, by immigrants, by people of a different faith" (Serwer, 2020).

Another incident of his appeal to the support of white racists and anti-semites was his reaction to a rally organized by a group of white racist organizers, including the Ku Klux Klan and the Alt-Knights (the military wing of the far-right, neo-fascist Proud Boys) that were ostensibly protesting a decision by the Charlottesville city government to have a statue of the Confederate general Robert $\mathrm{E}$. Lee removed. While Trump would have received direct information from his national security advisors about the sponsorship of this group, he equated this group with protestors against the group asserting: "You also had fine people on both sides" (Coaston, 2019). On August 11, the night before the rally, about two hundred of the attendees carrying lit torches paraded through the University of Virginia Campus shouting: "Jews will not replace us" (Coaston, 2019). Trump referred to these assembled groups as "people protesting very quietly" (Coaston 2019). The following day the rally "Unite the Right" was held in the vicinity of the monument in which a counter protestor was killed when a car was driven into a group of counter protestors. Along similar lines, as the Pentagon was con- 
sidering renaming Southern military bases named after Confederate generals, and offensive to many black members of our military-which is made up of $40 \%$ "minorities." Trump publicly indicated he would refuse to sign the annual defense authorization bill if Congress renamed the bases named after Confederate generals (Baker \& Cooper, 2020). Subsequently, the Defense Budget allowing such renaming was vetoed by Trump and then Congress voted to override the veto. It is important to keep in mind that the cause these Confederate generals were fighting for was the maintenance of the slavery of blacks in the South and that they were in revolt against the United States of America. Also, in his loss of the 2020 presidential election, Trump wanted the votes in the cities of Philadelphia, Milwaukee and Detroit, cities with large non-white populations thrown out due to undocumented charges of fraud (Badger, 2020). So what he seemed to be saying is nonwhite votes against him were illegitimate and if only the white vote counted, he would have been the winner.

As already indicated Trump's appeal to white racism is very explicit. His politics is attractive to those who are white racists and to other whites who are, at least, indifferent to his history of white racism. So it is of interest to go back and view how much of the white vote Barak Obama and his opponent received in two presidential elections and then to review how much of this vote Donald Trump received in his campaigns. In 2008 Obama received 43\% of the white vote and his opponent John McCain received 55\% (Pew Research Center, 2012). In his 2012 Presidential campaign against Mitt Romney, Obama received 39\% of the white vote as opposed to Romney's 59\% (Tyson \& Maniam, 2016). In 2016, in Trump's successful presidential campaign, he received 59\% of the white vote as compared to Hillary Clintons $37 \%$. (In the formerly Confederate South, Trump won a significant majority of white women receiving $64 \%$ of that vote in comparison to Clinton's 36\%). In his defeat by Joseph Biden in 2020, Trump received $58 \%$ of the white vote in comparison with Joe Biden's $41 \%$ (Election Exit Polls, 2020). If you estimate that a significant part of the Republican vote over the past four presidential election are overt white racists it becomes clear that the Republican Party feels that it needs this sector of their vote in a coalition in order to be competitive in a presidential election.

\section{Contemporary Race and Politics at the State Level}

Another area in which the Republican Party often is involved in seeking to suppress black votes is that Party's response to the Supreme Court's (2013) 5 - 4 decision in Shelby County v. Holder in which the Supreme Court declared the formula for requiring prior federal authorization and in general review ordinarily by the U.S. Federal District Court of the District of Columbia of changes election laws in States and other jurisdiction with a apparent tendency to suppress black or other language groups from securing the right to vote as outdated and inapplicable. The Voting Rights Act's reach had been further extended by the Supreme Court's 1969 decision in Allen v State Board of Elections which had ruled that an individual or organization with standing can challenge Section 5 violations 
in the Federal District Court where the violation is alleged. The language of the 1965 Voting Rights Act also sought to protect the voting rights of citizens-"language minorities"-whose primary language was not English. The criteria for such protections had been explicitly laid out in 1975 Voting Rights Act (Hunter, 1976).

Chief Justice John G. Roberts, Jr.'s opinion maintained that in order for Congress to again address racial discrimination by law it had to develop a formula to address current conditions where the old formulas dealing with suppressing black and other minority voters no longer applied. The old formula applied to states with overt discrimination such as literacy tests or to voter registration or turnout levels below 50 percent. An illustration of earlier efforts to suppress black votes was Mississippi's "bubble test" where black voters were asked to indicated how many bubbles there are in a bar of soap. Ruth Bader Ginsburg in speaking for the 4 member minority observed that "Throwing out preclearance when it worked and is continuing to work to stop discriminatory changes is like throwing away your umbrella in a rainstorm because you are not getting wet." Following Shelby, Texas and North Carolina immediately passed election law changes that federal courts later viewed as intentionally seeking suppression of black voters (Brennan Center for Justice, 2018). The number of restrictions passed by North Carolina's legislature and signed by the Governor on August 12, 2013 reduced the early voting period, making more difficult new voter registration, reducing Sunday voting, eliminating same day registration, and eliminating provisional ballots for people trying to vote in the wrong precinct. In declaring these restrictions as specifically aimed at black voters-who often had work requirements making it difficult to get to the polls or lack of auto ids, Judge Diana Motz's opinion representing the $4^{\text {th }}$ Circuit Court of Appeal declared the North Carolina statute invalid on July 29, 2016 as it violated provisions of the federal Voting Rights Act as well as the $15^{\text {th }}$ Amendment's injunction that rights of citizens should not be "denied or abridged ...by any State on account of race, color or previous condition of servitude." She noted that: "Because of race, the legislation enacted one of the largest restrictions of franchise in North Carolina history" and that "... the new provisions target African Americans with almost surgical precision" and quoting another case she noted that "this bares the mark of intentional discrimination" (United States Court of Appeals, 2016). Currently, the Voting Rights Enforcement Act seeking to reestablish preclearance voting rights protection passed the House of Representatives in 2019 with only one Republican member supporting it. And the Republican Majority Leader in the Senate, Mitch McConnell, the great, great grandson of slaveholders, has opposed allowing the House bill to be put on the floor for a vote in the Senate both as a Senate minority and majority leader (Ross, 2020). He has also opposed the broader voting rights bill before Congress, HR1/S1, the For The People Act.

\section{Conclusion}

So in spite of the fact that the U.S. had an interracial black president for two terms and recently has elected a black and south Asian woman, Kamala Harris, 
as the incoming Vice President, the deep and long-term presence of racism in our history is still a significant factor in American politics. This has been a persistent and disturbing factor since the beginning of "the American experiment". The United States continues to struggle with what Gunnar Myrdal termed "the American Dilemma" between the ideal of equality and racial justice and the politics of racism in the United States (Myrdal, 1996) - as evidenced by the difficulty in bringing an updated voting rights proposal to the floor of the U.S. Senate and the number of restrictive voting rights proposals being offered at the state level. Additionally, such a race-focused politics acts as a barrier to focusing on social and economic reforms needed in response to the changing nature of contemporary American society.

\section{Conflicts of Interest}

The author declares no conflicts of interest regarding the publication of this paper.

\section{References}

Badger, E. (2020). The Cities Central to Fraud Conspiracy Theories Didn't Cost Trump the Election. The New York Times, 16 November 2020. https://nytimes/21EXOyl

Baker, P., \& Cooper, H. (2020). Trump Rejects Military Bases Named After Confederate Generals. The New York Times, 10 June 2020, A2. https://www.nytimes.com

Belamonte Jr., J. V. (1999). The Spirit of Vengeance. Baton Rouge, LA: Louisiana State University Press.

Blight, D. W. (2020). An American Pogrom. The New York Review of Books, 25, 25-27.

Brennan Center for Justice (2018). The Effects of Shelby County v. Holder. New York, NY: Brennan Center for Justice. https://www.brennancenter.org

Coaston, J. (2019). Trump's New Defense of His Charlottesville Comments Is Incredibly False.Vox, 26 April 2019. https://jane.coaston@vox.com

Doctorow, E. L. (2008). The White Whale. The Nation, 14 July 2008.

DuBois, W. E. B. (1935). Black Reconstruction in America. New York, NY: Harcourt Brace.

Election Exit Polls (2020). The New York Times. https://www.nytimes.com/

Foner, E. (2009). Give Me Liberty: An American History. New York, NY: W.W. Norton.

Hunter, D. H. (1976). The 1975 Voting Rights Act and Language Minorities. Catholic University Law Review, 25, 250-270.

https://www.scholarship.law.edu/lawreview/vol25iss2/4

Kunzru, H. (2020). The Wages of Whiteness. The New York Review of Books, 54, 54-57.

Man Jr., A. P. (1951). Labor Competition and the New York Draft Riots of 1863. The Journal of Negro History, 36, 375-405. https://doi.org/10.2307/2715371

Maxwell, A. (2019). What We Get Wrong About the Southern Strategy. The Washington Post, 26 July 2019. http://www.washingtonpost.com

Myrdal, G. (1996) The American Dilemma: The Negro Problem and Modern Democracy. Abington; Philadelphia, PA: Routledge.

Perlstein, R. (2012). Lee Atwater's Infamous 1981 Interview on the Southern Strategy. The 
Nation, 13 November 2012.

Pew Research Center (2012). 7 November 2012.

Roediger, D. (1999). The Wages of Whiteness: Race and the American Working Class. London and New York, NY: Verso Books.

Ross, J. (2020). Mitch McConnell's Complicated History on Voting Rights. NBC News, 23 July 2020. https://www.nbcnews.com

Schwart, J. (2015). Some Things about Ronald Reagan You Won't Hear at the Reagan Library Debate. The Intercept, 16 September 2015.

Schwartzapful, B., \& Keller, B. (2015). Willie Horton Revisited. The Marshall Project, 13 May 2015.

Serwer, A. (2020). Birtherism and Trump. The Atlantic, 13 May 2020.

Staples, B. (2020). The Haunting of Tulsa, Okla. The New York Times, 28 December 2020, A14.

Tyson, A., \& Maniam, M. (2016). Behind Trump's Victory: Divisions by Race, Gender, Education. Pew Research Center, 9 November 2016.

U.S. Supreme Court (2013). Shelby County, Ala v. Holder (Vol. 133, U.S. 2612).

U.S. Supreme Court (1969). Allen v. State Board of Elections (Vol. 393, U.S. 544).

United States Court of Appeals (2016). North Carolina State Conference of the NAACP v. McCrory (831 4th Cir. 2016).

Wehner, P. (2011). The GOP and the Birther Trap. Wall Street Journal, 14 April 2011.

Withers, R. (2018). George H.W. Bush's “Willie Horton” Ad Will Always Be the Reference Point for Dog Whistle Racism. Vox 1 December 2018. https://www.vox.com

Yellin, E. S. (2016). Racism in the Nation's Service. Chapel Hill, NC: University of North Carolina Press.

Zucchino, D. (2021). Wilmington's Lies: The Murderous Coup of 1898 and the Rise of White Supremacy. Washington DC: Atlantic Monthly. 